\title{
Decreased autophagy: a major factor for cardiomyocyte death induced by $\beta_{1}$-adrenoceptor autoantibodies
}

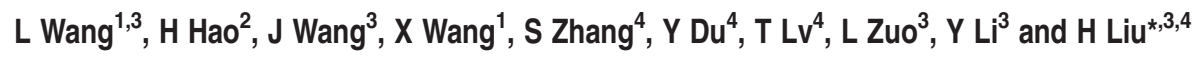

Cardiomyocyte death is one major factor in the development of heart dysfunction, thus, understanding its mechanism may help with the prevention and treatment of this disease. Previously, we reported that anti- $\beta_{1}$-adrenergic receptor autoantibodies $\left(\beta_{1}-\mathrm{AABs}\right)$ decreased myocardial autophagy, but the role of these in cardiac function and cardiomyocyte death is unclear. We report that rapamycin, an mTOR inhibitor, restored cardiac function in a passively $\beta_{1}$-AAB-immunized rat model with decreased cardiac function and myocardial autophagic flux. Next, after upregulating or inhibiting autophagy with Beclin-1 overexpression/rapamycin or RNA interference (RNAi)-mediated expression of Beclin-1/3-methyladenine, $\boldsymbol{\beta}_{1}$-AAB-induced autophagy was an initial protective stress response before apoptosis. Then, decreased autophagy contributed to cardiomyocyte death followed by decreases in cardiac function. In conclusion, proper regulation of autophagy may be important for treating patients with $\beta_{1}$-AAB-positive heart dysfunction.

Cell Death and Disease (2015) 6, e1862; doi:10.1038/cddis.2015.237; published online 27 August 2015

Heart dysfunction is the terminal stage of various cardiovascular diseases, and it is characterized by a complicated etiology and high mortality. Recent studies indicate that cardiomyocyte death was a leading contributor to the development of heart dysfunction. ${ }^{1}$ Because systolic and diastolic function is directly affected by myocardial cell loss, understanding how cardiomyocyte death occurs will inform treatment strategies to prevent or treat heart dysfunction.

Since the 1990s, studies have revealed that diverse cardiovascular diseases are correlated to anti- $\beta_{1}$-adrenergic receptor autoantibodies $\left(\beta_{1}-\mathrm{AABs}\right)^{2,3}$ We reported that $\beta_{1}$ $A A B s$ were induced by myocardial remodeling in heart dysfunction, ${ }^{4}$ and that its long-term presence significantly decreased cardiac function in vivo. ${ }^{5} \beta_{1}$-AABs also caused cell death of cultured adult rat ventricular myocytes and this was attributed to apoptosis. ${ }^{6}$ Recently, work from our laboratory ${ }^{7}$ and others ${ }^{8}$ indicated that $\beta_{1}$-AABs induced myocardial apoptosis. However, $\beta_{1}-A A B$-induced cardiomyocyte death was not completely reversed with the caspase inhibitor Z-VAD$\mathrm{fmk},{ }^{6}$ indicating that other factors were involved in $\beta_{1}-\mathrm{AAB}$ induced cardiomyocyte death.

Presently, we observed that $\beta_{1}-\mathrm{AABs}$ decrease myocardial autophagy that maintains cellular homeostasis. ${ }^{9}$ Deficiencies in autophagy allow the accumulation of damaged, denatured or aging proteins ${ }^{10}$ and organelles, ${ }^{11}$ and this will cause cell death. To date, the role of $\beta_{1}-A A B$-induced changes in autophagy as related to cardiac function and cardiomyocyte death is unclear. Therefore, we characterized $\beta_{1}-\mathrm{AAB}$-induced changes in myocardial autophagy and identified a role for this in cardiac function and cardiomyocyte death. Our data will inform future studies of $\beta_{1}-\mathrm{AAB}$-positive heart dysfunction and suggest a treatment window for autophagy regulation.

\section{Results}

$\beta_{1}$-AABs caused the decrease of cardiac function in passively immunized rats. Rats were passively immunized by injecting $\beta_{1}$-AABs $(2 \mu \mathrm{g} / \mathrm{g})$, once every 10 days, for 80 days. Before each immunization, serum $\beta_{1}$-AABs were measured and it increased 20 days after passive immunization. Serum $\beta_{1}-A A B s$ remained stable until the end of the experiment in the $\beta_{1}-\mathrm{AAB}$ group compared with the control group (Supplementary Figure S1a).

Meanwhile, cardiac function was measured 40 and 60 days after passive immunization, and there was no significant difference in left ventricular function between the immunized and control groups. However, animals had significantly decreased left ventricular systolic pressure (LVSP), maximal positive and negative values of the instantaneous first derivative of left ventricular pressure $\left(+d P / d t_{\max }\right.$ and $\left.-d P / d t_{\max }\right)$ and significantly increased left ventricular end diastolic pressure (LVEDP) 80 days after passive immunization in the $\beta_{1}-A A B$ group compared with the control group (Supplementary Figure S1b-e), indicating that a long-term

\footnotetext{
${ }^{1}$ Department of Pathology, Shanxi Medical University, Taiyuan, Shanxi, PR China; ${ }^{2}$ Department of Orthopaedics, Shanxi Dayi Hospital (Shanxi Academy of Medical Sciences), Taiyuan, Shanxi, PR China; ${ }^{3}$ Department of Physiology, Shanxi Medical University, Taiyuan, Shanxi, PR China and ${ }^{4}$ Department of Physiology and Pathophysiology, School of Basic Medical Sciences, Capital Medical University, Beijing, PR China

${ }^{*}$ Corresponding author: H Liu, Department of Physiology and Pathophysiology, School of Basic Medical Sciences, Capital Medical University, 10 Xitoutiao, You An Men, Beijing 100069, PR China. Tel: +86 10 83911830; Fax: +86 10 83911830; E-mail: liuhr2000@126.com

Abbreviations: $\beta_{1}$-AABs, anti- $\beta_{1}$-adrenergic receptor autoantibodies; RNAi, RNA interference; LVSP, left ventricular systolic pressure; $+\mathrm{dP} / \mathrm{dt} t_{\text {max }}$, maximal positive values of the instantaneous first derivative of left ventricular pressure; $-\mathrm{dP} / \mathrm{dt}_{\mathrm{max}}$, maximal negative values of the instantaneous first derivative of left ventricular pressure; LVEDP, left ventricular end diastolic pressure; RAPA, rapamycin; CQ, chloroquine; 3-MA, 3-methyladenine; $\beta_{1}$-AR-ECII, the second extracellular loop of $\beta_{1}$-adrenoceptor; MAP1LC3, LC3, microtubule-associated protein 1 light chain 3; PI3K, phosphatidylinositol-3-kinase; DMEM, Dulbecco's modified Eagle's medium; FBS, fetal bovine serum; CCK-8, cell counting kit-8

Received 25.3.2015; revised 27.6.2015; accepted 20.7.2015; Edited by G Melino
} 
presence of $\beta_{1}$-AABs could cause a significant decrease in cardiac function.

Decreased autophagy had a role in decreased cardiac function induced by $\boldsymbol{\beta}_{1}$-AABs. In this study, Beclin-1, an important gene in autophagic regulation, and LC3, a protein marker for autophagy, were selected to measure autophagy. Significantly decreased LC3 and Beclin-1 protein were observed 20 days after passive immunization and lower levels persisted 40 and 80 days after passive immunization in the $\beta_{1}-A A B$ group (Figures $1 a-c$ ), indicating that $\beta_{1}$-AABs may lead to decreased autophagy in myocardial tissues. To confirm the results, p62 protein, which was degraded within the autolysosomes, was used as a marker of autophagic flux. At 20 days after immunization, p62 protein in cardiac tissue increased significantly in the $\beta_{1}$-AAB group compared with control groups and $\mathrm{p} 62$ remained relatively high at 40 and 80 days (Figures $1 \mathrm{a}$ and d), indicating a defect in autophagic flux in the presence of $\beta_{1}$-AABs.

Rapamycin (RAPA), an mTOR inhibitor, is often used to upregulate autophagy. ${ }^{12}$ In this experiment, it was used to improve autophagy in rat myocardial tissue (Supplementary Figure S2). Significantly improved left ventricular function was observed in rats pretreated with rapamycin compared with those only passively immunized in the $\beta_{1}$-AAB group (Figures $2 a-d$ ), suggesting that upregulating autophagy may reverse decreased cardiac function induced by $\beta_{1}$-AABs and that insufficient autophagy caused by the long-term presence of $\beta_{1}$-AABs may be associated with decreased cardiac function.

$\boldsymbol{\beta}_{1}$-AABs caused the death of $\mathrm{H} 9 \mathrm{c} 2$ cells. Cell viability was measured to reflect the effects of $\beta_{1}$-AABs stimulation of different durations. Significantly decreased cell viability was observed $12 \mathrm{~h}$ after $\beta_{1}$-AABs stimulation and at a minimum of
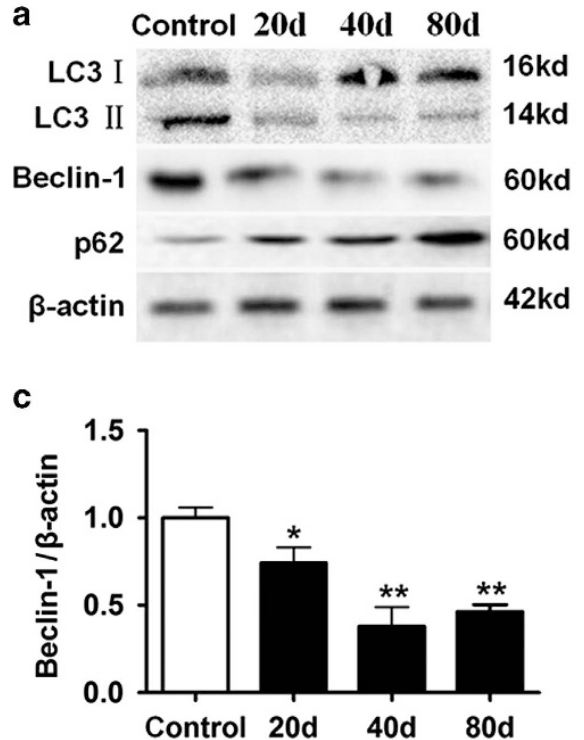

$36 \mathrm{~h}$ after $\beta_{1}$-AABs stimulation (Figure $3 a$ ), indicating that $\beta_{1^{-}}$ AABs may cause the death of myocardial cells.

$\mathrm{LDH}$ is released when cell membranes lyse, and it is an indicator of cell damage. Significantly increased LDH activity was observed at $6 \mathrm{~h}$ which lasted till the end of the experiment compared with the control group (Figure $3 b$ ), suggesting that $\beta_{1}$-AABs may directly damage $\mathrm{H} 9 \mathrm{c} 2$ cells.

Decreased autophagy was critical for cardiomyocyte death. LC3 and Beclin-1 were used to indicate autophagy, and Beclin-1 and LC3 protein and mRNA in H9c2 myocardial cells were measured $0,12,24,36$, and $48 \mathrm{~h}$ after $\beta_{1}$-AABs stimulation using western blot and real-time PCR. In situ expression of LC3 protein was measured with immunostaining. Beclin-1 protein decreased $24 \mathrm{~h}$ after $\beta_{1}$-AABs stimulation, dropped to a minimum at $36 \mathrm{~h}$ and recovered to normal at $48 \mathrm{~h}$ compared with the control group (Figures $4 \mathrm{a}$ and $\mathrm{c}$ ). Beclin-1 mRNA expression significantly decreased $12 \mathrm{~h}$ after $\beta_{1}$-AABs stimulation and it was minimal at $36 \mathrm{~h}$ and gradually recovered compared with the control group (Figure $4 \mathrm{f}$ ). Both LC3 protein (see Figures $4 a$ and b) and LC3 mRNA (see Figure $4 \mathrm{e}$ ) were decreased $12 \mathrm{~h}$ after $\beta_{1}$-AABs stimulation, and were minimal at $36 \mathrm{~h}$, returning to normal at $48 \mathrm{~h}$ compared with the control group. Immunostaining revealed that green punctate fluorescent signals representing LC3 significantly decreased $36 \mathrm{~h}$ after $\beta_{1}$-AABs stimulation, but recovered at $48 \mathrm{~h}$ (Figures $4 \mathrm{~g}$ and $\mathrm{h}$ ). Thus, $\beta_{1}$-AABs could decrease myocardial autophagy.

In addition, p62 was used to reflect autophagic flux. Figures $4 \mathrm{a}$ and $\mathrm{d}$ show that $\mathrm{p} 62$ protein increased significantly $12 \mathrm{~h}$ after $\beta_{1}$-AABs stimulation, peaked at $36 \mathrm{~h}$, and then recovered at $48 \mathrm{~h}$ compared with controls. Meanwhile, chloroquine (CQ) was used to block autophagosome-lysosome fusion. Chloroquine rescued LC3 and p62 for $36 \mathrm{~h}$ after $\beta_{1}$-AABs stimulation (Figures $4 i-k$ ), indicating that autophagic flux decreases in the presence of $\beta_{1}$-AABs.
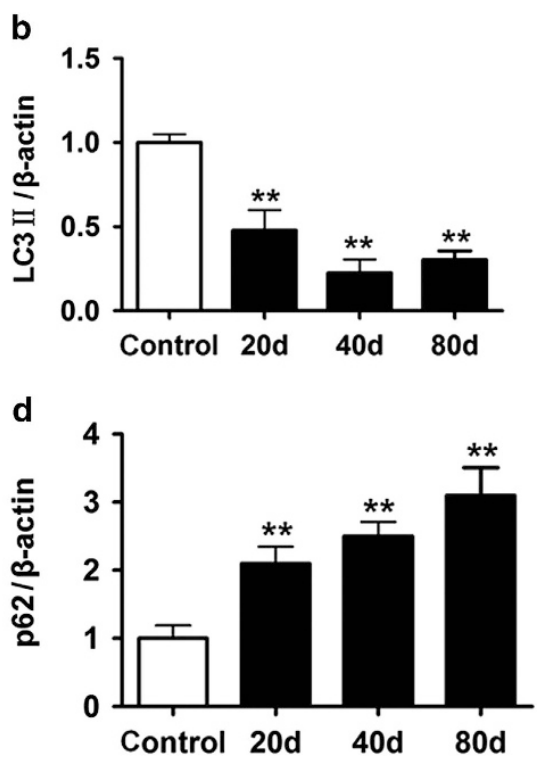

Figure 1 Change in autophagic flux induced by $\beta_{1}$-AABs in myocardial tissues at 20, 40, and 80 days after passive immunization. (a) Representative western blots of autophagy markers LC3, Beclin-1, and p62 in lysates from control and $\beta_{1}$-AAB rats. Each lane represents an individual animal. (b-d) Quantification of western blot data from (a). Data are presented as means \pm S.D. ( $n=6$ per group). ${ }^{*} P<0.05 ;{ }^{* *} P<0.01$ 
a
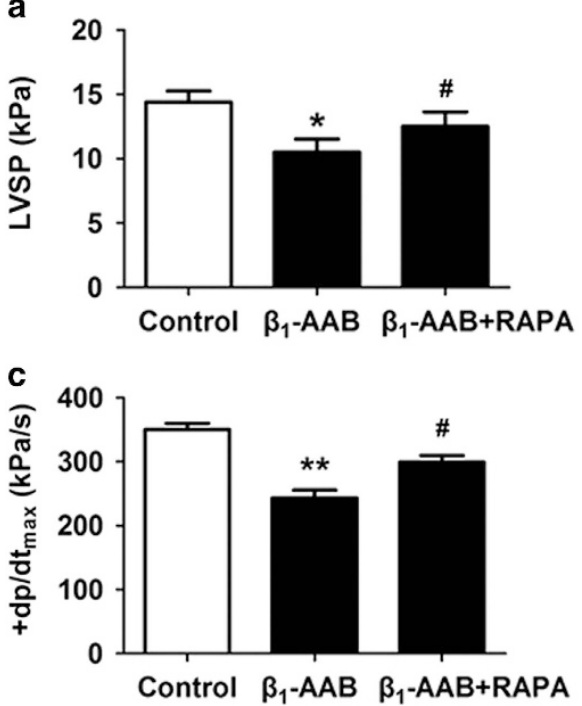
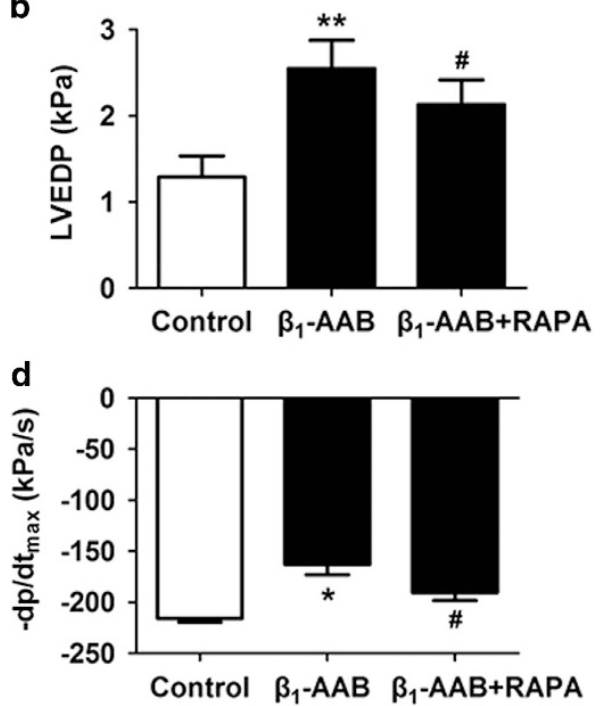

Figure $2 \beta_{1}$-AAB-induced decrease in cardiac function was reversed by upregulating autophagy using mTOR inhibitor rapamycin (RAPA). Cardiac function was measured with LVSP $(\mathbf{a}), \operatorname{LVEDP}(\mathbf{b}),+\mathrm{dP} / \mathrm{dt}_{\max }(\mathbf{c})$, and $-\mathrm{dP} / \mathrm{dt}_{\max }(\mathbf{d}) .+\mathrm{dP} / \mathrm{dt} t_{\max }$ means maximal positive values of the instantaneous first derivative of left ventricular pressure and $-d P / d t_{\max }$ means negative values of the instantaneous first derivative of left ventricular pressure. LVSP and $+d P / d t_{\max }$ are the parameters of systolic function. LVEDP and $-\mathrm{dP} / \mathrm{dt}_{\max }$ are the indicators of diastolic function ( $n=6$ per group). Data are expressed as means \pm S.D. ${ }^{\star} P<0.05,{ }^{\star *} P<0.01$ versus Control; ${ }^{*} P<0.05$ versus $\beta_{1}-\mathrm{AAB}$ group
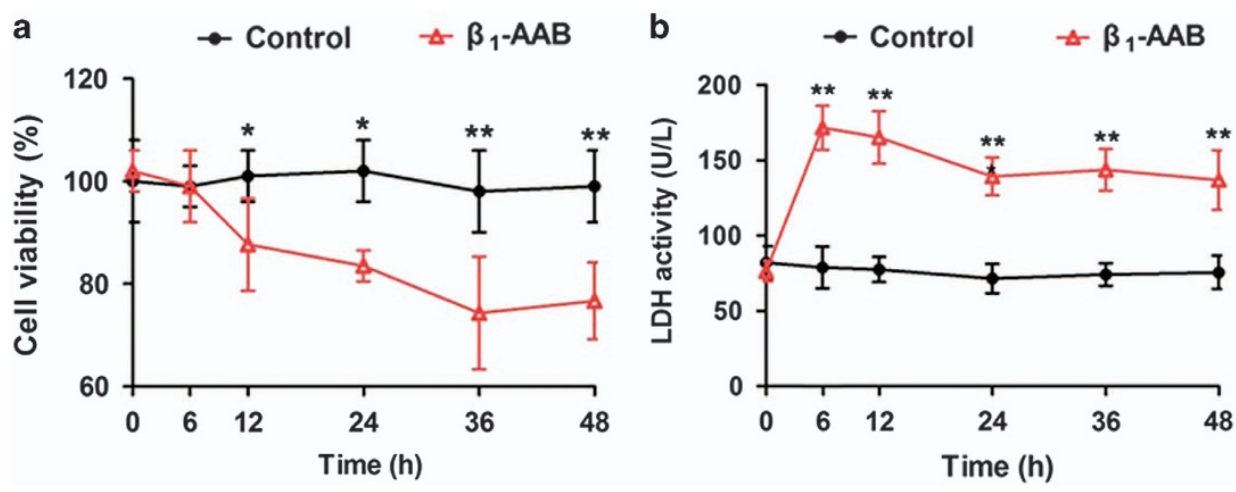

Figure 3 Effect of $\beta_{1}$-AABs stimulation on $\mathrm{H} 9 \mathrm{c} 2$ myocardial cells at different time points. H9c2 cells were treated with $\beta_{1}-\mathrm{AABs}(1 \mu \mathrm{mol} / \mathrm{l})$ or negative lgGs $(1 \mu \mathrm{mol} / \mathrm{l})$ at different time points. (a) Cell viability was measured by CCK-8 assay ( $n=16$, means \pm S.D.) ${ }^{*} P<0.05 ;{ }^{*} P<0.01$. (b) LDH activity was measured to evaluate the extent of cell damage $(n=16$, means \pm S.D. $){ }^{* *} P<0.01$

Cell viability decreased the most $36 \mathrm{~h}$ after $\beta_{1}$-AABs stimulation in $\mathrm{H} 9 \mathrm{c} 2$ myocardial cells. Therefore, $36 \mathrm{~h}$ was selected as the time point for $\beta_{1}$-AABs treatment. Recombinant plasmid pcDNA3.1-Beclin-1 for upregulating autophagy (Supplementary Figures $\mathrm{S} 3 \mathrm{a}-\mathrm{e}$ ) and recombinant plasmid expressing small interfering RNA targeting Beclin-1 (Beclin-1shRNA) to inhibit autophagy (Supplementary Figures S4a-f) were transfected into $\mathrm{H} 9 \mathrm{c} 2$ cells, followed by $\beta_{1}$-AABs stimulation for $36 \mathrm{~h}$. Empty negative control plasmid for protein overexpression and shRNA expression did not influence autophagy (Supplementary Figures S3a-e, S4a-f) and cell viability (Supplementary Figures S3f and S4g). Cell viability increased in cells with upregulated autophagy, but decreased in cells with inhibited autophagy compared with mock cells (Figure 4I). To confirm these data, rapamycin or 3-methyladenine (3-MA) were used to upregulate or suppress autophagy, and cell viability of $\mathrm{H} 9 \mathrm{c} 2$ myocardial cells was measured (Figure $4 \mathrm{~m}$ ). Two different ways to increase or inhibit autophagy yielded similar results, suggesting that
$\beta_{1}$-AAB-induced decreases in autophagy have a role in cardiomyocyte death.

Increased autophagy benefitted myocardial cells with early $\boldsymbol{\beta}_{1}$-AABs stimulation. Autophagy is well known as a stress response, ${ }^{13}$ so we observed changes in this stress over time, using earlier $\beta_{1}$-AABs simulation. Cells were collected $0,30 \mathrm{~min}, 1,3,6$, and $12 \mathrm{~h}$ after stimulation and LC3 protein, LC3 mRNA, beclin-1 protein, beclin-1 mRNA, and p62 protein were measured. Autophagy increased early as LC3 protein (see Figures $5 a$ and b), LC3 mRNA (see Figure $5 e$ ), beclin-1 protein (see Figures $5 a$ and $c$ ), and beclin-1 mRNA (see Figure $5 \mathrm{f}$ ) increased $30 \mathrm{~min}$ after $\beta_{1}$-AABs treatment and remained high for 1 and $3 \mathrm{~h}$ and recovered to normal at $6 \mathrm{~h}$ compared with controls. At $12 \mathrm{~h}$, expression decreased. Meanwhile, p62 protein was declined at $30 \mathrm{~min}$, remained low at 1 and $3 \mathrm{~h}$, returned to normal at $6 \mathrm{~h}$, and then increased at $12 \mathrm{~h}$ (Figures $5 \mathrm{a}$ and $\mathrm{d}$ ). These data are consistent with results mentioned above, in which 
a
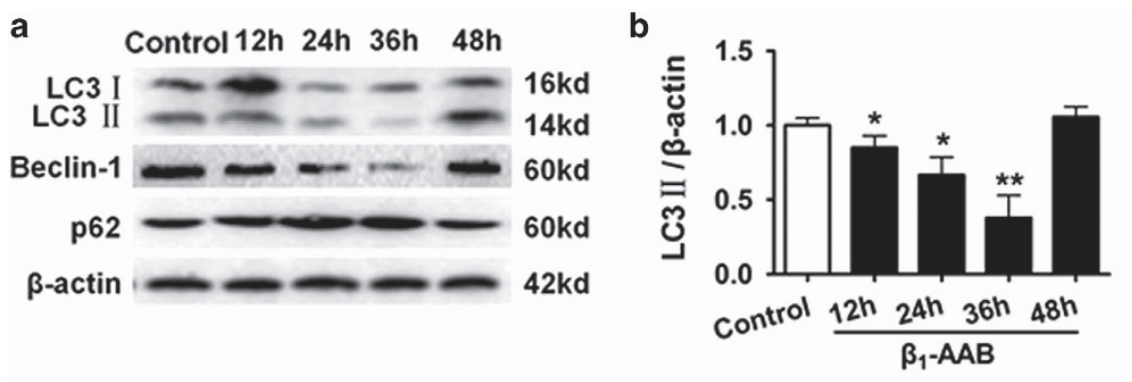

d

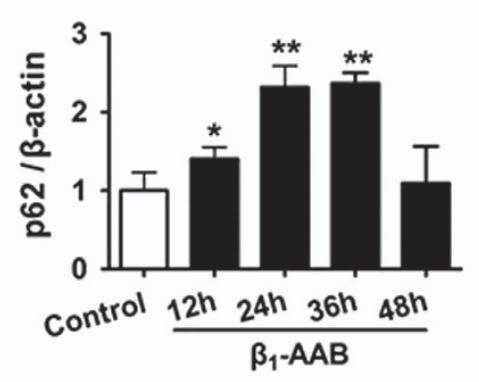

g

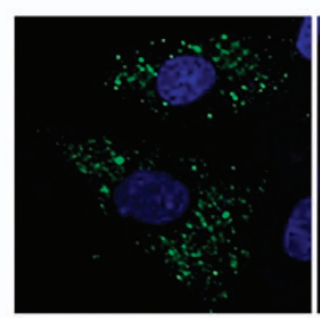

Control

i
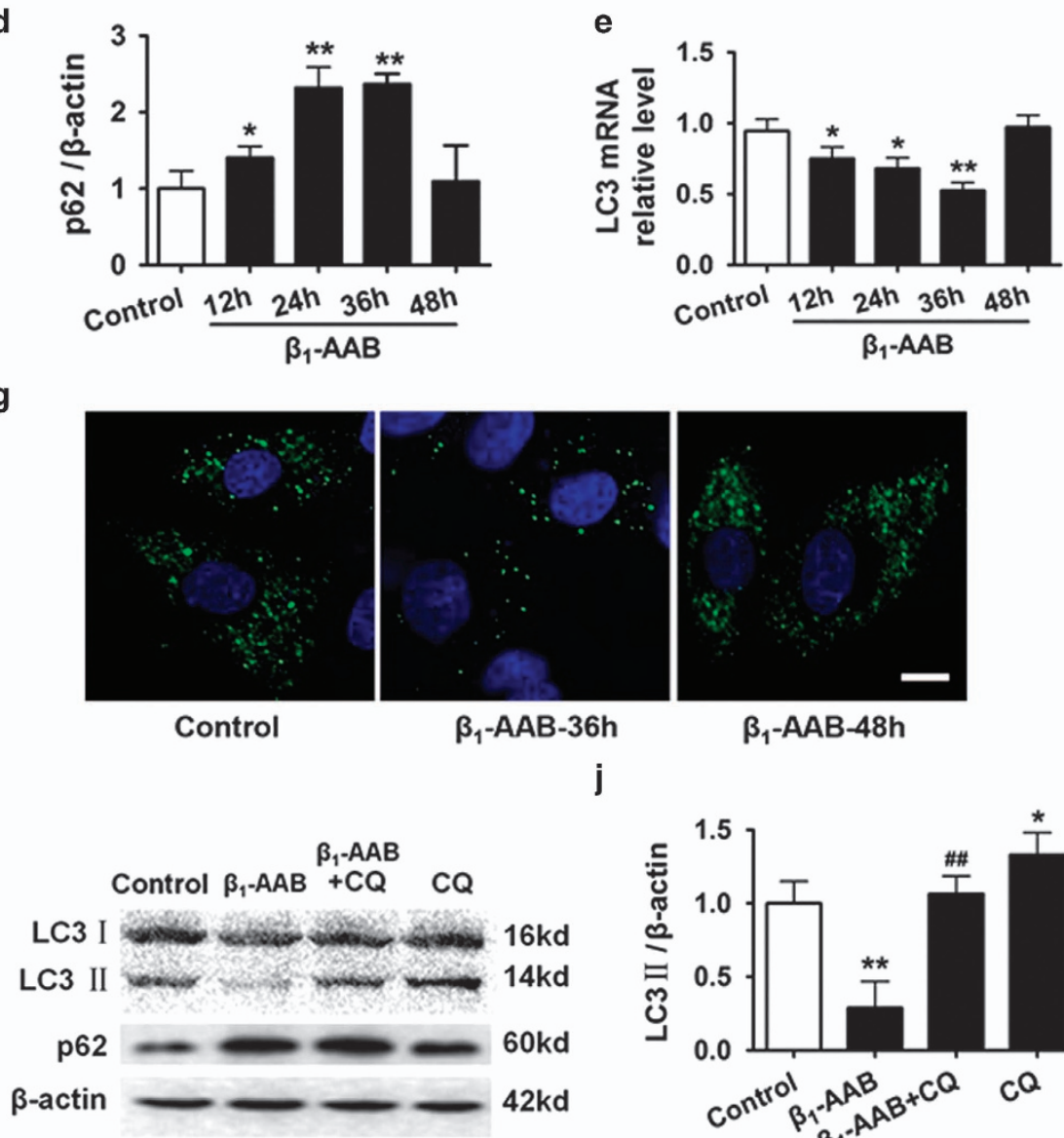

$$
\beta_{1} \text {-AAB-36h } \quad \beta_{1}-A A B-48 h
$$

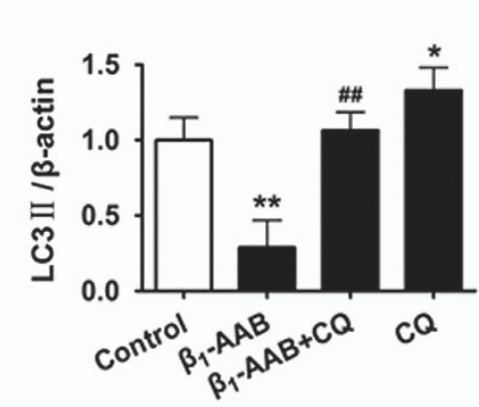

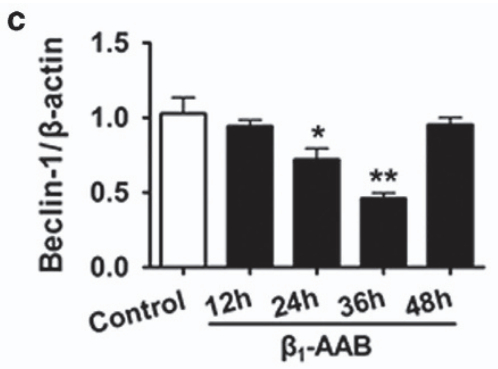
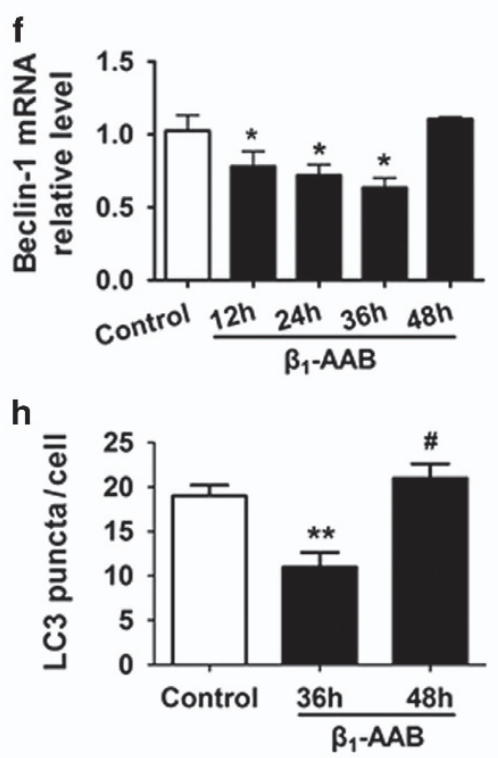

k

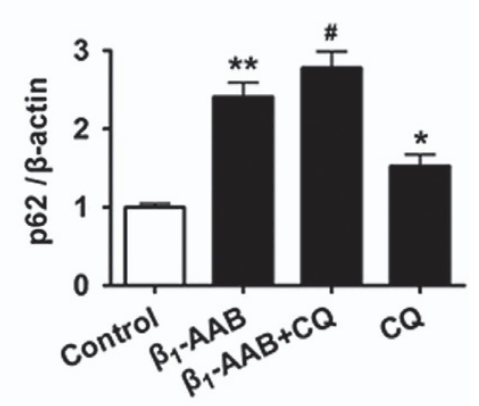

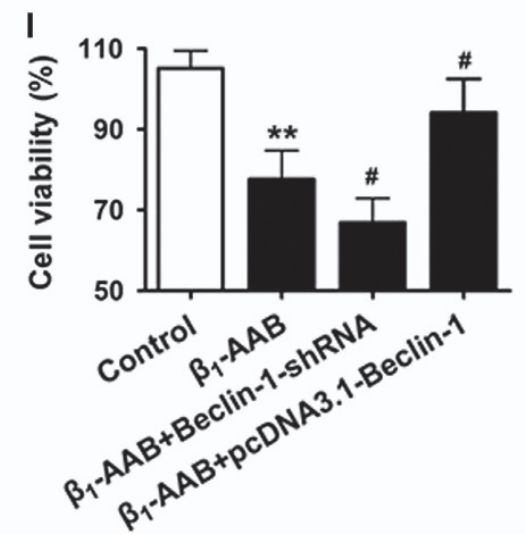

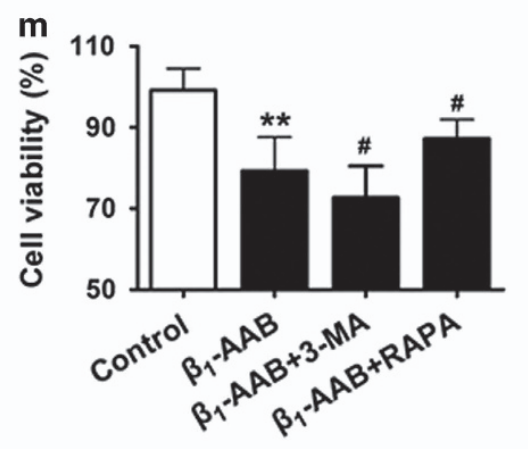


a

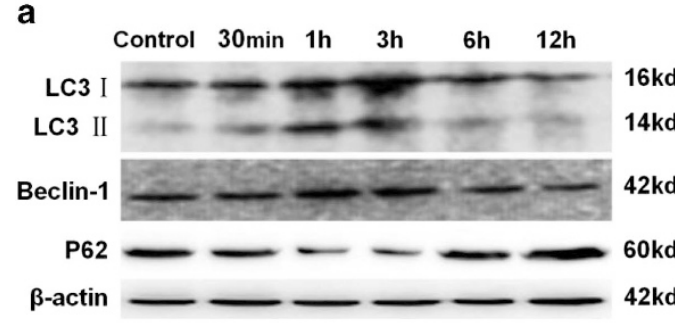

d

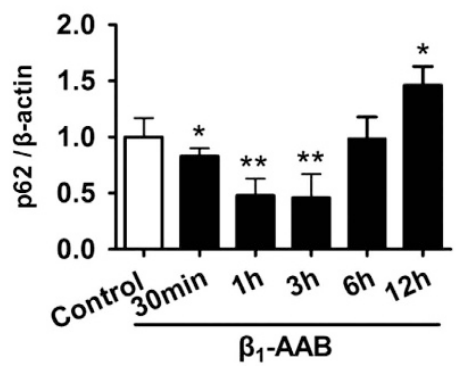

g

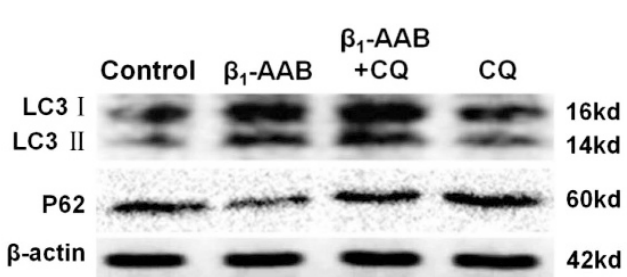

b

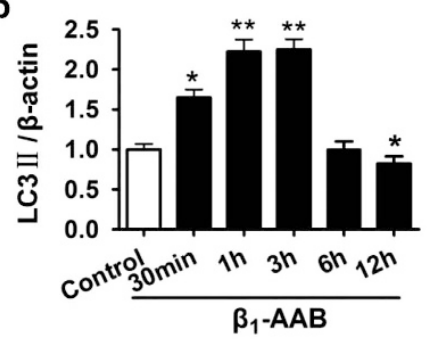

e

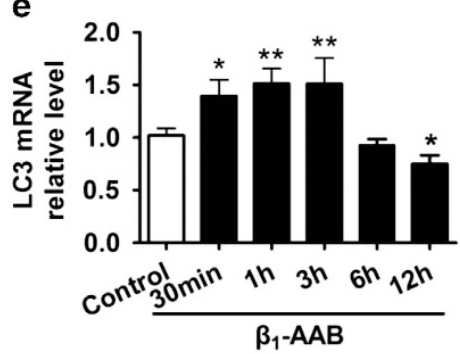

h

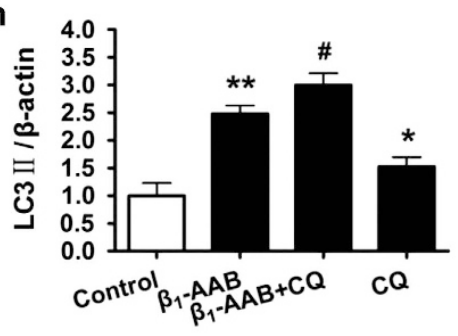

C

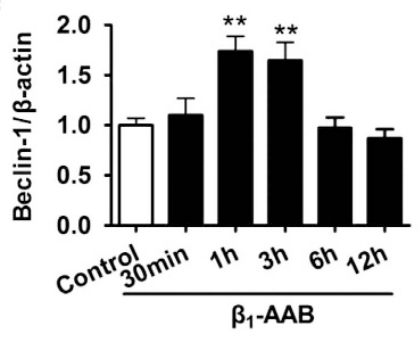

f

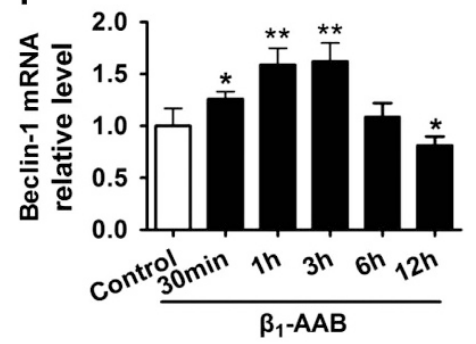

i

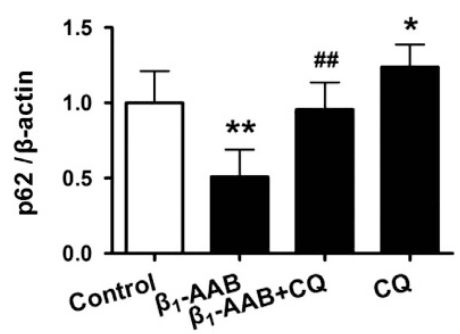

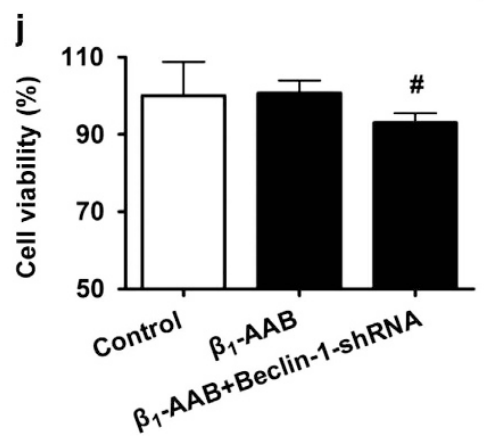

k

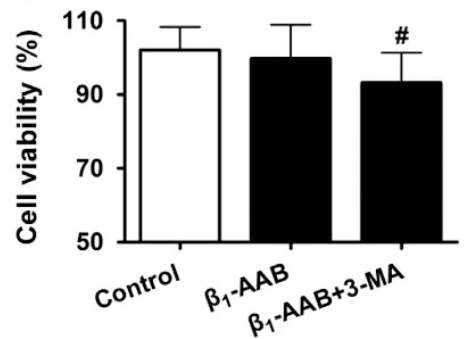

Figure 5 Effect of early $\beta_{1}$-AABs stimulation on autophagy in $\mathrm{H} 9 \mathrm{c} 2 \mathrm{cells}$ and its importance on cardiomyocyte death. (a) Representative western blots of autophagy markers LC3, Beclin-1, and p62 at 0, $30 \mathrm{~min}, 1 \mathrm{~h}, 3 \mathrm{~h}, 6 \mathrm{~h}$, and $12 \mathrm{~h}$ after $\beta_{1}$-AABs stimulation. (b-d) Quantification of western blot data from (a). Data are expressed as means \pm S.D. ( $n=6$ per group). ${ }^{*} P<0.05 ;{ }^{* *} P<0.01$. (e and f) After exposure to $\beta_{1}$-AABs for different time, LC3 and Beclin- 1 mRNA were measured by real-time PCR. Data are presented as means \pm S.D. ( $n=6$ per group). ${ }^{*} P<0.05$; ${ }^{*} P<0.01$. (g) Western blot showed the protein expression of LC3, and $p 62$ after $3 \mathrm{~h} \beta_{1}$-AABs stimulation in H9c2 cells pretreated with/or without $20 \mu \mathrm{M}$ chloroquine (CQ). (h and i) Quantification of western blot data from (g). Data are expressed as means \pm S.D. $\left(n=6\right.$ per group). ${ }^{*} P<0.05,{ }^{* *} P<0.01$ versus Control; ${ }^{\#} P<0.05,{ }^{\# \#} P<0.01$ versus $\beta_{1}-\mathrm{AAB}$ group. (j and $\mathbf{k}$ ) Cardiomyocyte death was enhanced by inhibiting autophagy (Beclin1-shRNA or $3-\mathrm{MA}$ ) $6 \mathrm{~h}$ after $\beta_{1}-\mathrm{AAB}$ stimulation. Cell viability was determined by CCK-8. $\left(n=8\right.$, means \pm S.D.) ${ }^{\#} P<0.05$ versus $\beta_{1}-\mathrm{AAB}$ group

Figure 4 Change of autophagic flux induced by $\beta_{1}-\mathrm{AABs}$ in $\mathrm{H} 9 \mathrm{c} 2$ myocardial cells and its effect on cardiomyocyte death. (a) H9c2 myocardial cells were treated with $\beta_{1}$-AABs or negative IgGs at $0,12,24,36$, and 48 h. Western blot indicated protein expression of LC3, Beclin-1, and p62 in H9c2 cells. (b-d) Quantification of western blot data from (a). Data are expressed as means \pm S.D. ( $n=6$ per group). ${ }^{*} P<0.05$; ${ }^{* *} P<0.01$. (e and f) Real-time PCR was used to measure LC3 and Beclin-1 mRNA expression in H9c2 cells. Data are expressed as means \pm S.D. ( $n=6$ per group). ${ }^{*} P<0.05 ;{ }^{* *} P<0.01$. (g) Representative images of immunofluorescence staining for LC3 (green) and DAPI (blue) in H9c2 cells. Scale bar was $10 \mu \mathrm{m}$. (h) A statistical analysis by counting LC3 puncta in 20 different fields. The number of LC3 puncta/cell was evaluated as the total number of dots (green) divided by the number of nuclei (blue) in each microscopic field. Data are expressed as means \pm S.D. $\left(n=6\right.$ per group). ${ }^{* *} P<0.01$ versus Control; ${ }^{\#} P<0.05$ versus $\beta_{1}-\mathrm{AAB}$ group. (i) $\mathrm{H} 9 \mathrm{c} 2$ cells were pretreated with/or without $20 \mu \mathrm{M}$ chloroquine (CQ, an inhibitor of autophagy), and immunoblotting assays were performed with LC3B or p62 antibodies at $36 \mathrm{~h}$ after $\beta_{1}$-AABs stimulation. ( $\mathbf{j}$ and $\mathbf{k}$ ) Quantification of western blot data from (i). Data are expressed as means \pm S.D. $\left(n=6\right.$ per group). ${ }^{*} P<0.05,{ }^{* *} P<0.01$ versus Control; ${ }^{\#} P<0.05,{ }^{\#} P<0.01$ versus $\beta_{1}$-AAB group. (I and $\mathbf{m}$ ) Change in cell viability $36 \mathrm{~h}$ after $\beta_{1}$-AABs stimulation when myocardial autophagy was upregulated by overexpressing Beclin-1/RAPA or inhibited by RNA interference against Beclin-1/3-MA. Data are expressed as means \pm S.D. $\left(n=8\right.$ per group). ${ }^{*} P<0.01$ versus Control; ${ }^{\#} P<0.05$ versus $\beta_{1}-\mathrm{AAB}$ group 
autophagy decreased to the minimum $36 \mathrm{~h}$ after $\beta_{1}$-AABs stimulation. Therefore, the presence of $\beta_{1}$-AABs first induced increased autophagic flux in myocardial cells and this may deplete autophagic genes or proteins and cause insufficient autophagy.

To better interpret changes in LC3, chloroquine was used to block the fusion of the autophagosome with the lysosome, and Figures $5 \mathrm{~g}-\mathrm{i}$ show that pretreatment with chloroquine could upregulate LC3 and p62 significantly for $3 \mathrm{~h}$ after $\beta_{1}$-AABs stimulation, indicating that early increases in LC3 offer efficient autophagic flux.

To confirm that $\beta_{1}-A A B$ induced early increases in autophagy on cardiomyocyte death, autophagy was inhibited with Beclin-1 using RNA interference technology or 3-MA. In addition, because early increased autophagy recovered to almost normal $6 \mathrm{~h}$ after stimulation, $6 \mathrm{~h}$ was chosen for observation to eliminate the effect of later decreases in autophagy and diminished cell viability. Data show that cell viability did not change $6 \mathrm{~h}$ after $\beta_{1}$-AABs stimulation of myocardial cells, but cardiomyocyte death occurred when autophagy was inhibited (Figures 5j and k).

\section{Discussion}

The objective of this study is to explore the importance of $\beta_{1}$-AAB-induced reduction of myocardial autophagy on cardiac function in vivo, and discuss changes in $\beta_{1}-A A B-$ induced autophagy over time and its significance on cardiomyocyte death. We observed that changes in $\beta_{1}$-AABinduced autophagy increased early and then decreased. The early increase was cardioprotective, but the later decrease in autophagy prompted cardiomyocyte death and reduced cardiac function in vivo.

Recently, autoantibodies against the second extracellular loop of $\beta_{1}$-adrenoceptor ( $\beta_{1}$-AR-ECII) ( $\beta_{1}$-AABs) were detected in the sera of patients with idiopathic dilated cardiomyopathy, ${ }^{2}$ Chagas' heart disease, ${ }^{3}$ and heart dysfunction caused by ischemic cardiomyopathy. ${ }^{14}$ In our previous study, the long-term presence of autoantibodies may contribute to decreased cardiac function in a rat model immunized with the peptide corresponding to the second extracellular loop of $\beta_{1}$-adrenoceptor. ${ }^{5}$ In this study, a passively immunized rat model was established to eliminate the influence of antigen peptide itself on the body ${ }^{15}$ and this also approximated human $\beta_{1}$-AABs in the rat models. ${ }^{16}$ During model establishment, IgG purified from actively immunized rats was administered to rats to observe the effect of $\beta_{1}$-AABs on cardiac function and we found that $\beta_{1}-\mathrm{AABs}$ could decrease cardiac function.

It has been reported that reduced autophagy is a major contributor to heart dysfunction, ${ }^{17}$ and upregulated autophagy can significantly improve impaired cardiac function. ${ }^{18}$ Autophagy is a catabolic process by which cells degrade dysfunctional cytoplasmic components and it is necessary for maintenance of cellular homeostasis. ${ }^{19}$ Impaired autophagy causes mitochondrial dysfunction and accumulation, which is closely associated with many human diseases. ${ }^{11}$ Generally, LC3 and Beclin-1 are used to monitor autophagy. Microtubuleassociated protein 1 light chain 3 (MAP1-LC3, LC3) is currently a more reliable biomarker to observe autophagy, ${ }^{20}$ and the expression of soluble I-type LC3 (LC3-I) in the cytoplasm is regular. When autophagy occurs, LC3-I converts to LC3-II through ubiquitin-like modification and LC3-II then binds to and localizes in the autophagosomal membrane. LC3-II is well correlated with the number of formed autophagosomes. ${ }^{21}$ As a component of phosphatidylinositol3-kinase $(\mathrm{PI} 3 \mathrm{~K})$ that is necessary in autophagic pathway, ${ }^{22}$ Beclin-1 has an essential role in the formation of autophagosome precursors and membranes, ${ }^{23}$ and is a common index in the observation of autophagy. In addition to LC3 and Beclin-1, p62 are markers for studying autophagic flux. ${ }^{24}$ p62 binds directly to LC3 and is degraded within the autolysosomes, ${ }^{25}$ so accumulation of p62 indicates inhibition of autophagy. ${ }^{26}$ In a previous study, we confirmed that the long-term existence of $\beta_{1}$-AABs reduced autophagy in myocardial tissues. ${ }^{9}$ Similarly, in this study, we also observed that $\beta_{1}$-AABs could decrease myocardial autophagy in a passively immunized rat model. Increased $p 62$ protein indicated a defect in autophagy induced by $\beta_{1}$-AABs. To observe the effect of decreased autophagy on cardiac function, the mTOR inhibitor rapamycin was used to upregulate autophagy. Data show that decreased cardiac function induced by $\beta_{1}$-AABs was effectively reversed by enhanced autophagy. Thus, decreased myocardial autophagy is a major contributor to heart dysfunction.

Myocardial cells are a basic unit of cardiac systolic and diastolic function and when they are damaged or dead, contractile proteins in myocardial cells are degraded immediately, decreasing contractility. To identify a role for $\beta_{1}$-AABs in myocardial cells, we purified IgG antibody in actively immunized rat serum to obtain $\beta_{1}$-AABs. Next, a relatively stable $\mathrm{H} 9 \mathrm{c} 2$ cell line was selected from embryonic rat heart tissues, and this line was used to observe the effects of $\beta_{1}$-AABs on survival and autophagy of myocardial cells under the same conditions and time points. Data show that cardiac cell viability deceased at $12 \mathrm{~h}$ after $\beta_{1}$-AABs stimulation and was minimal at $36 \mathrm{~h}$, suggesting that $\beta_{1}$-AABs may directly cause cardiomyocyte death. To confirm these data, LDH was measured in myocardial cells because this is documented to leak from damaged cells. ${ }^{27} \mathrm{LDH}$ activity in the cell culture medium significantly increased $6 \mathrm{~h}$ after $\beta_{1}$-AABs stimulation, indicating damage. In conclusion, $\beta_{1}$-AABs stimulation directly harmed the myocardial cell membrane, and caused cell death. This conclusion is consistent with previous results made by Jane-wit et al in an adult rat model. ${ }^{6}$

Previously, $\beta_{1}$-AABs were confirmed to induce apoptosis in cultured neonatal rat myocardial cells. ${ }^{7}$ Staudt's group ${ }^{28}$ also pointed out that $\beta_{1}$-AABs could cause apoptosis in adult isolated myocardial cells. Thus, we measured $\beta_{1}-\mathrm{AAB}$ effects on myocardial apoptosis over time and found increased apoptosis $6 \mathrm{~h}$ after $\beta_{1}$-AABs stimulation and a return to normal at $24 \mathrm{~h}$. Next, the caspase inhibitor Z-VAD-fmk was used to inhibit apoptosis and we observed that cardiomyocyte death recovered to a certain extent $36 \mathrm{~h}$ after $\beta_{1}$-AABs stimulation (Supplementary Figure S5), indicating that $\beta_{1}$-AAB-induced apoptosis is involved in cardiomyocyte death. Because $\beta_{1}$-AAB-induced cardiomyocyte death was not completely recovered via apoptotic inhibition, other mechanisms are at play. Thus, we studied $\mathrm{H} 9 \mathrm{c} 2$ cells with $\beta_{1}$-AABs at different time points and observed decreased autophagic flux $12 \mathrm{~h}$ after stimulation and this was minimal at $36 \mathrm{~h}$, indicating that 
$\beta_{1}$-AABs stimulation decreased myocardial autophagic flux. Also, comparing changes of autophagy and myocardial cell viability over time after $\beta_{1}$-AABs stimulation, we noted that myocardial cell viability started to decrease $12 \mathrm{~h}$ after stimulation, when autophagy decreased dramatically, indicating that the decline of autophagy induced by $\beta_{1}$-AABs may cause cardiomyocyte death. Thus, we used recombinant plasmid pcDNA3.1-Beclin-1 and recombinant plasmidexpressing small interfering RNA targeting Beclin-1 (Beclin-1-shRNA) to upregulate and inhibit myocardial autophagy. Autophagy is reported to be upregulated by increasing or suppressing Beclin-1 expression. ${ }^{29}$ Thus, H9c2 cells were transfected with recombinant plasmid pcDNA3.1-Beclin-1 to upregulate autophagy and we observed that cell viability was higher after $\beta_{1}-\mathrm{AABs}$ stimulation in transfected cells compared with cells treated with only $\beta_{1}-\mathrm{AABs}$. In addition, Beclin-1 RNA interference plasmid was used to transfect $\mathrm{H} 9 \mathrm{c} 2$ cells to inhibit autophagy and cell viability decreased after $\beta_{1}$-AABs stimulation. However, beclin-1 could not only induce the autophagy, but also it could suppress autophagosome-lysosome fusion, ${ }^{30}$ so data are difficult to interpret when beclin-1 manipulation is used to modulate autophagy. Therefore, we measured cell viability of $\mathrm{H} 9 \mathrm{c} 2$ myocardial cells pretreated with rapamycin to upregulate autophagy or 3-MA to suppress autophagy and both yielded similar results. Therefore, decreased autophagy promotes cardiomyocyte death and improvements in autophagy benefit cardiac function.

Autophagy is commonly regarded as a stress response. ${ }^{13}$ $\mathrm{H} 9 \mathrm{c} 2$ myocardial cells were treated with $\beta_{1}$-AABs at earlier time points ( $0,30 \mathrm{~min}, 1,3$, and $6 \mathrm{~h}$ ) and autophagy was found to first increase and then decrease. However, increased LC3 can be associated with either increased autophagic initiation or reduced degradation in the lysosome. To better distinguish between these two scenarios, chloroquine was applied and data show that the early increase in LC3 means efficient autophagic flux. So the increased autophagy after short-term $\beta_{1}-A A B s$ stimulation is a stress response, and later depletion of autophagic genes and proteins decreases autophagy. Additional investigations are needed to learn whether $\beta_{1}$-AABs directly induced these changes in myocardial cells. To verify the effect of early increased autophagy after $\beta_{1}$-AABs stimulation on cardiomyocyte death, $\mathrm{H} 9 \mathrm{c} 2$ cells were transfected with Beclin-1-shRNA or 3-MA to inhibit autophagy and we found that myocardial survival was significantly reduced after early $\beta_{1}$-AABs stimulation due to inhibition of autophagy. In addition, comparing changes in apoptosis and autophagy over time, autophagy increased before apoptosis. This early increase of autophagy was cardioprotective but this effect gradually disappeared as autophagy decreased and cells died.

In conclusion, autophagy is a stress response before apoptosis in $\beta_{1}$-AAB-induced cardiomyocyte death, and decreased autophagy becomes a subsequent reason for cardiac dysfunction caused by $\beta_{1}$-AAB-induced cardiomyocyte death. Thus, autophagic regulation is more important than apoptosis for patients with $\beta_{1}$-AAB-positive heart dysfunction.

Our study is limited because we only observed that a lack of autophagy caused by $\beta_{1}-\mathrm{AABs}$ decreased cardiomyocyte death. However, the role of apoptotic changes with autophagic upregulation or inhibition in cardiomyocyte death induced by $\beta_{1}-A A B s$ requires more study. In addition, validating whether $\beta_{1}$-AAB-induced cardiomyocyte death could be completely reversed by Z-VAD-fmk plus rapamycin is unknown. Still, we conclude that decreased autophagy is a major factor for cardiomyocyte death induced by $\beta_{1}$-AABs. Our preliminary observations may open new insights into the pathogenesis and prevention of $\beta_{1}$-AAB-positive heart dysfunction.

\section{Materials and Methods}

Animals. Male healthy Wistar rats (8 weeks of age, 140-160 g) obtained from the Animal Center of Shanxi Medical University were used in this study. The experimental procedures were approved by the Institutional Committee on Animal Care of Shanxi Medical University and performed in accordance with the Guide for the Care and Use of Laboratory Animals according to the regulation in the People's Republic of China.

Extraction of $\boldsymbol{\beta}_{1}$-AABs. First, a $\beta_{1}$-AAB-positive animal model was established by actively immunizing rats with the second extracellular loop antigen peptide of $\beta_{1}$-adrenergic receptor $\left(\beta_{1}\right.$-AR-ECII), as described in the previous studies. ${ }^{9}$ Then, animal sera from the $\beta_{1}$-AAB-positive group (actively immunized) and the control group were collected and extracted using MAbTrap Kit (GE Healthcare, 17-1128-01, Uppsala, Sweden) for affinity and purification of lgG.

Passive immunization and rapamycin treatment. Animals were randomized into passive immunization $\left(\beta_{1}-\mathrm{AAB}\right)$ and control (negative $\mathrm{lg} \mathrm{G}$ ) groups. In the $\beta_{1}-\mathrm{AAB}$ group, $\beta_{1}-\mathrm{AAB}$-positive $\lg \mathrm{G}$ extracted as depicted above was administered to animals via the caudal vein $(2 \mu \mathrm{g} / \mathrm{g})$. This operation was carried out every 10 days and lasted for 80 days. Before each immunization, animal blood samples were collected via tail vein and then the sera were prepared to determine $\beta_{1}$-AABs. In control group, $\beta_{1}$-AAB-negative IgG was administrated by the exact same immunization and determination procedure as $\beta_{1}-A A B$ group. A subset of animals were treated with rapamycin (RAPA, Sigma, R0395, St. Louis, MO, USA) in $\beta_{1}-\mathrm{AAB}$ group $\left(\beta_{1}-\mathrm{A} A \mathrm{~B}+\mathrm{RAPA}\right.$ group). RAPA stock solution was prepared by dissolving rapamycin in DMSO $(25 \mathrm{mg} / \mathrm{ml})$ and stored until dilution with PBS for intraperitoneal injection. Because $\beta_{1}$-AAB-induced decreases in myocardial autophagy occur on day 20 after passive immunization, RAPA administration started 3 days before this decrease (day 18), beginning at $0.5 \mathrm{mg} / \mathrm{kg} /$ day in the first 3 days and then adjusted to $0.25 \mathrm{mg} / \mathrm{kg} / \mathrm{day}^{31}$ until the end of this study.

ELISA. ELISA was performed using synthesized peptides corresponding to the sequence of the second extracellular loops of human $\beta_{1}$-adrenoceptors as described previously. ${ }^{32}$ First, $50 \mu \mathrm{l}$ of the peptide $(50 \mu \mathrm{g} / \mathrm{ml})$ in $100 \mathrm{mM} \mathrm{Na}_{2} \mathrm{CO}_{3}$ solution ( $\mathrm{pH}$ 11.0) was coated on a microtiter plate (NUNC, Roskilde, Denmark) overnight at $4{ }^{\circ} \mathrm{C}$. Next, the wells were saturated with PMT (PBS containing $3 \%$ skimmed milk (W/N), $0.1 \%$ Tween 20 (V/V) and $0.01 \%$ thimerosal (W/V)) for $1 \mathrm{~h}$ at $37^{\circ} \mathrm{C}$. After washing the wells three times with PBS-T, $5 \mu$ of sera was added to $95 \mu \mathrm{l}$ of PMT solution and incubated for $1 \mathrm{~h}$ at $37^{\circ} \mathrm{C}$. After additional washing in PBS-T solution three more times, an affinity-purified biotinylated sheep anti-rat IgG $(\mathrm{H}+\mathrm{L})$ antibody (1 : 2000 dilution, Beijing Zhongshan Golden Bridge Biotechnology, ZB-2040, Beijing, China) was added and reacted for $1 \mathrm{~h}$ at $37^{\circ} \mathrm{C}$. The plates were washed with PBS-T for three times. The bound biotinylated antibody was detected by incubating the plates with horseradish peroxidase streptavidin (1:3000 dilution, Vector, SA-5004, Burlingame, CA, USA) for $1 \mathrm{~h}$. The wells were washed with PBS-T

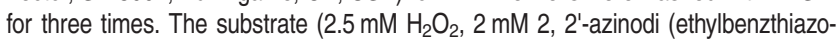
line) sulfuric salt (ABTS, Bio Basic Inc., AD0002, Markham, ON, Canada)) was added. Optical density was measured after $30 \mathrm{~min}$ at $405 \mathrm{~nm}$ by a microplate reader (Molecular Devices Corp., Sunnyvale, CA, USA). Positive reactions of sera against peptides were verified as described by Liu et al. ${ }^{32}$

In vivo measurements of cardiac function. With reference to our previous study, ${ }^{4}$ after anesthesia, a cannula was inserted into the left ventricle via the right carotid artery. BL-410 biological signal recording and analysis system was used to record and analyze the following: the left ventricular systolic pressure (LVSP), left ventricular end diastolic pressure (LVEDP), and maximal positive and negative values of the instantaneous first derivative of left ventricular pressure $\left(+d P / d t_{\max }\right.$ and $\left.-d P / d t_{\max }\right)$. 
Cell culture and transfection. Rat myocardial cell-derived cell line H9c2 was purchased from Cell Bank of China Science Academy (Shanghai, China). Cells were cultured in Dulbecco's modified Eagle's medium (DMEM) (Hyclone, SH30022.01B) containing 10\% fetal bovine serum (FBS) (Sijiqing, W0001, Hangzhou, China), $100 \mathrm{U} / \mathrm{ml}$ penicillin and $100 \mu \mathrm{g} / \mathrm{ml}$ streptomycin (Solarbio, $\mathrm{P} 1400-100$, Beijing, China), and incubated in the atmosphere with $5 \% \mathrm{CO}_{2}$ at $37^{\circ} \mathrm{C}$. Cells were transfected with pcDNA3.1-Beclin-1 (Beclin-1 gene over-expressed, RefSeq Number: NM_053739.2) or Beclin-1-shRNA transfectant (Beclin-1 gene partially-silenced, RefSeq Number: NM_053739.2) using Lipofectamine 2000 (Invitrogen, 11668-027, Grand Island, NY, USA) according to the protocol supplied by the manufacturer. Then, 48-72 $\mathrm{h}$ after transfection, mock cells and transfected cells were treated with $\beta_{1}$-AABs $(1 \mu \mathrm{mol} / /)$ or negative lgGs $(1 \mu \mathrm{mol} / /)$ for a specified time. The empty plasmid (control-pcDNA3.1 and control-shRNA) was used as a negative control for protein overexpression and shRNA expression.

Reagent treatment of $\mathbf{H} 9 \mathrm{c} 2$ cells. H9c2 cells were treated with $\beta_{1}$-AABs $(1 \mu \mathrm{mol} / \mathrm{l})$ or negative $\mathrm{lgGs}(1 \mu \mathrm{mol} / /)$ for different points or pretreated with $10 \mathrm{ng} / \mathrm{ml}$ RAPA or $5 \mathrm{mM}$ 3-MA (Sigma, M9281) or $20 \mu \mathrm{M}$ chloroquine (Sigma-Aldrich, C6628, St. Louis, MO, USA) for $30 \mathrm{~min}$ and then treated with $\beta_{1}$-AABs $(1 \mu \mathrm{mol} / \mathrm{l})$ at different times in the continued presence of RAPA, 3-MA, or chloroquine. The vehicle for RAPA was DMSO (0.1\% total volume). 3-MA and chloroquine were dissolved in PBS.

Measurement of LDH activity. At different time points, a bulk of H9c2 cells were selected and treated with $\beta_{1}-\mathrm{AABs}$ ( $\beta_{1}-\mathrm{AAB}$ group) or negative lgGs (Control group), and then $0.5 \mathrm{ml}$ of culture supernatant was collected. LDH activity, which reflects the extent of cellular damage, was measured with a colorimetric assay kit (Nanjing Jiancheng Biochemical Reagent Co., Nanjing, China) according to the protocol supplied by the manufacturer. Assay sample absorbances were measured at $450 \mathrm{~nm}$.

Cell viability assay. Cell viability was measured with a cell counting kit-8 (CCK-8). H9c2 cells were inoculated in 96-well plates $\left(1 \times 10^{4}\right.$ cells) and cells were treated with $\beta_{1}$-AABs at different time points. Then, $10 \mu$ l CCK-8 (Dojindo Molecular Technologies, CK04, Kumamoto, Japan) was added to the plates and cells were incubated for $4 \mathrm{~h}$ at $37^{\circ} \mathrm{C}$. Sample absorbance was measured at $450 \mathrm{~nm}$ with a microplate reader by the following equation: viability $\%=[(A S-A B) /(A C-A B)] \times$ $100 \%$, where AS is the absorbance of the samples with $\beta_{1}-\mathrm{AABs}, \mathrm{AC}$ is the absorbance of the DMEM media, and AB is the absorbance of the control.

\section{LC3, Beclin-1, and p62 protein measurement by western blot.} Western blot was used to quantify LC3 and Beclin-1 expression in tissues and cells. After specific treatments, cardiac tissue $(70 \mathrm{mg}$ ) was lysed in RIPA buffer (Beyotime Biotech, P0013B, Haimen, China) or total proteins were isolated from cells using cell lysis buffer (Cell Signaling, \#9803, Beverly, MA, USA). Then, supernatant fluids were collected after centrifugation and protein was quantified with BCA Protein Assay Kit (Thermo Scientific, 23225, Rockford, IL, USA). First, $40 \mathrm{mg}$ of sample was loaded and separated by SDS-PAGE and then transferred onto a PVDF membrane (Millipore, IPVH00010, Billerica, MA, USA) followed by addition of primary antibodies against anti-Beclin-1 monoclonal (1: 1000; Santa Cruz, sc-48381, Dallas, TX, USA), anti-LC3B monoclonal (1: 1000; Cell Signaling Tech, 2775, Beverly, MA, USA), anti-SQSTM1/p62 polyclonal (1: 1000; Cell Signaling Tech, 5114) and anti- $\beta$ actin monoclonal (1:1000; Sigma-Aldrich, A1978) at $4^{\circ} \mathrm{C}$ overnight. Next, the membrane was blotted with the corresponding secondary antibody for $1 \mathrm{~h}(1: 3000$; Beijing Zhongshan Golden Bridge Biotechnology, ZB-2305, ZB-2301). The blot was developed using a SuperEnhanced chemiluminescent detection kit, and then the membrane was placed in a Kodak Image Station 400 (Eastman Kodak Co., Rochester, NY, USA) for exposure and images of membrane signal bands were obtained using Kodak ID Software (Eastman Kodak Co.).

LC3 and Beclin-1 mRNA measurement with real-time PCR. Realtime PCR was used to measure LC3 and Beclin-1 mRNA in H9c2 cells. Approximately $3 \mu \mathrm{g}$ of total RNA was extracted from cells and reverse transcribed to cDNA. The thermal profile of SYBR Green PCR included $30 \mathrm{~s}$ heat activation of the enzyme at $95^{\circ} \mathrm{C}$ followed by 40 cycles of denaturation at $95^{\circ} \mathrm{C}$ for $5 \mathrm{~s}$ and annealing/extension at $60^{\circ} \mathrm{C}$ for $20 \mathrm{~s}$. The primer sequences were as follows: $L C 3$, sense: $5^{\prime}$-CATGCCGTCCGAGAAGACCT-3' and antisense: $5^{\prime}$-GATGAGCCGGACA TCTTCCACT-3' (GenBank accession number, NM022867.2); Beclin-1, sense: 5'-TTGGCCAATAAGATGGGTCTGAA-3' and antisense: 5'-TGTCAGGGACTCCAG ATACGAGTG-3' (GenBank accession number, NM001034117.1). Expression was standardized to GAPDH and data, expressed as a fold-difference in the number of
LC3 or Beclin-1 copies relative to the number of GAPDH copies, were quantified by the relative quantitative $2^{-\Delta \Delta \mathrm{Ct}}$ method. $\Delta \Delta \mathrm{Ct}=\Delta \mathrm{Ct}$ (target gene) $-\Delta \mathrm{Ct}$ (GAPDH); $\Delta \mathrm{Ct}$ (target gene) $=\mathrm{Ct}$ (experimental - target) $-\mathrm{Ct}$ (control - target); and $\Delta \mathrm{Ct}(\mathrm{GAPDH})=\mathrm{Ct}($ experimental $-\mathrm{GAPDH})-\mathrm{Ct}($ control $-\mathrm{GAPDH})$.

Cell immunostaining. The in situ expression of LC3 protein in H9c2 cells was observed with immunostaining. $\mathrm{H} 9 \mathrm{c} 2$ cells were extracted from the medium and washed twice with precooled PBS. After fixation in $4 \%$ paraformaldehyde for $15 \mathrm{~min}$, cells were washed with $0.2 \%$ Triton in PBS three times for 3 min each time and then blocked with immunostaining blocking buffer (Beyotime Biotech, P0102) at room temperature for $1 \mathrm{~h}$. Primary LC3B antibody was added to the section (1:400, Cell Signaling Tech, 2775) at $4{ }^{\circ} \mathrm{C}$ overnight and subsequently reacted with FITC-labeled secondary fluorescence antibody of the corresponding species (1:50, Beijing Zhongshan Golden Bridge Biotechnology, ZF-0311). DAPI (Beyotime Biotech, C1005) was used to stain nuclei for $3 \mathrm{~min}$. Sections were mounted and observed under laser confocal microscopy (OLYMPUS, FV1000, Tokyo, Japan). Mean LC3 puncta per cell quantified from 20 different fields was measured by manual counting and DAPI-stained nuclei were counted as cells in the same fields. Then, LC3 puncta per cell were calculated by dividing total dot numbers by quantified nuclei per microscopic field.

Statistical analysis. Data are expressed as means \pm standard deviation (S.D.). Statistical analysis was performed with SPSS software (version 15.0, SPSS Inc., Chicago, IL, USA). A Student's t-test was used to compare the means of two independent samples and one-way ANOVA was applied after a Bonferroni post hoc test for more than two samples. Data were considered as statistically significant when $P<0.05$.

\section{Conflict of Interest}

The authors declare no conflict of interest.

Acknowledgements. This work was supported by the National Natural Sciences Foundation of China (Grant No. 31401006), 973 special preliminary study plan (Grant No. 2014CB560704), Beijing Key Laboratory of Metabolic Disorders Related Cardiovascular Disease Special Fund (Grant No. 2014DXWL03) and the Doctoral Startup Research Fund of Shanxi Medical University (Grant No. 03201407). We thank LetPub (www.letpub.com) for its linguistic assistance during the preparation of this manuscript.

1. Yamada T, Matsumori A, Wang WZ, Ohashi N, Shiota K, Sasayama S. Apoptosis in congestive heart failure induced by viral myocarditis in mice. Heart Vessels 1999; 14: $29-37$.

2. Magnusson $Y$, Wallukat G, Waagstein F, Hjalmarson A, Hoebeke J. Autoimmunity in idiopathic dilated cardiomyopathy. Characterization of antibodies against the beta 1adrenoceptor with positive chronotropic effect. Circulation 1994; 89: 2760-2767.

3. Rosenbaum MB, Chiale PA, Schejtman D, Levin M, Elizari MV. Antibodies to beta-adrenergic receptors disclosing agonist-like properties in idiopathic dilated cardiomyopathy and Chagas' heart disease. J Cardiovasc Electrophysiol 1994; 5: 367-375.

4. Liu HR, Zhao RR, Jiao XY, Wang YY, Fu M. Relationship of myocardial remodeling to the genesis of serum autoantibodies to cardiac beta(1)-adrenoceptors and muscarinic type 2 acetylcholine receptors in rats. J Am Coll Cardiol 2002; 39: 1866-1873.

5. Zuo L, Bao H, Tian J, Wang X, Zhang S, He Z et al. Long-term active immunization with a synthetic peptide corresponding to the second extracellular loop of beta1-adrenoceptor induces both morphological and functional cardiomyopathic changes in rats. Int $\mathrm{J}$ Cardiol 2011: 149: 89-94.

6. Jane-wit D, Altuntas CZ, Johnson JM, Yong S, Wickley PJ, Clark P et al. Beta 1-adrenergic receptor autoantibodies mediate dilated cardiomyopathy by agonistically inducing cardiomyocyte apoptosis. Circulation 2007; 116: 399-410.

7. Gao Y, Liu HR, Zhao RR, Zhi JM. Autoantibody against cardiac beta1-adrenoceptor induces apoptosis in cultured neonatal rat cardiomyocytes. Acta Biochim Biophys Sin 2006; 38: 443-449.

8. Mao W, Fukuoka S, Iwai C, Liu J, Sharma VK, Sheu SS et al. Cardiomyocyte apoptosis in autoimmune cardiomyopathy: mediated via endoplasmic reticulum stress and exaggerated by norepinephrine. Am J Physiol Heart Circ Physiol 2007; 293: H1636-H1645.

9. Wang L, Lu K, Hao H, Li X, Wang J, Wang K et al. Decreased autophagy in rat heart induced by anti-beta1-adrenergic receptor autoantibodies contributes to the decline in mitochondrial membrane potential. PLOS ONE 2013; 8: e81296.

10. Komatsu M, Ueno T, Waguri S, Uchiyama Y, Kominami E, Tanaka K. Constitutive autophagy: vital role in clearance of unfavorable proteins in neurons. Cell Death Differ 2007; 14 887-894.

11. Wrighton KH. Autophagy: shaping the fate of mitochondria. Nat Rev Mol Cell Biol 2011; 12 344-345. 
12. Meijer AJ, Codogno P. Regulation and role of autophagy in mammalian cells. Int J Biochem Cell Biol 2004; 36: 2445-2462.

13. Kim J, Kim YC, Fang C, Russell RC, Kim JH, Fan W et al. Differential regulation of distinc Vps34 complexes by AMPK in nutrient stress and autophagy. Cell 2013; 152: 290-303.

14. Zhang L, Hu D, Shi X, Li J, Zeng W, Xu L et al. Autoantibodies against the myocardium beta 1-adrenergic and M2-muscarinic receptors in patients with heart failure. Zhonghua Nei Ke Za Zhi 2001; 40: 445-447.

15. Jahns R, Boivin V, Hein L, Triebel S, Angermann CE, Ertl G et al. Direct evidence for a beta 1-adrenergic receptor-directed autoimmune attack as a cause of idiopathic dilated cardiomyopathy. J Clin Invest 2004; 113: 1419-1429.

16. Du Y, Yan L, Du H, Wang L, Ding F, Quan L et al. beta1 -adrenergic receptor autoantibodies from heart failure patients enhanced TNF-alpha secretion in RAW264.7 macrophages in a largely PKA-dependent fashion. J Cell Biochem 2012; 113: 3218-3228.

17. Sun A, Cheng Y, Zhang Y, Zhang Q, Wang S, Tian S et al. Aldehyde dehydrogenase ameliorates doxorubicin-induced myocardial dysfunction through detoxification of 4-HNE and suppression of autophagy. J Mol Cell Cardiol 2014; 71: 92-104.

18. Bhuiyan MS, Pattison JS, Osinska H, James J, Gulick J, McLendon PM et al. Enhanced autophagy ameliorates cardiac proteinopathy. J Clin Invest 2013; 123: 5284-5297.

19. Klionsky DJ, Emr SD. Autophagy as a regulated pathway of cellular degradation. Science 2000; 290: 1717-1721.

20. Mizushima N. Methods for monitoring autophagy. Int J Biochem Cell Biol 2004; 36: 2491-2502.

21. Shintani T, Klionsky DJ. Autophagy in health and disease: a double-edged sword. Science 2004; 306: 990-995.

22. Liang XH, Jackson S, Seaman M, Brown K, Kempkes B, Hibshoosh $\mathrm{H}$ et al. Induction of autophagy and inhibition of tumorigenesis by beclin 1. Nature 1999; 402: 672-676.

23. Takahashi Y, Coppola D, Matsushita N, Cualing HD, Sun M, Sato Y et al. Bif-1 interacts with Beclin 1 through UVRAG and regulates autophagy and tumorigenesis. Nat Cell Biol 2007; 9: 1142-1151.

24. Klionsky DJ, Abdalla FC, Abeliovich H, Abraham RT, Acevedo-Arozena A, Adeli K et al. Guidelines for the use and interpretation of assays for monitoring autophagy. Autophagy 2012; 8: 445-544.

25. Bjørkøy G, Lamark T, Brech A, Outzen H, Perander M, Øvervatn A et al. p62/SQSTM1 form protein aggregates degraded by autophagy and has a protective effect on huntingtin-induced cell death. J Cell Biol 2005; 171: 603-614.
26. Komatsu M, Waguri S, Koike M, Sou YS, Ueno T, Hara T et al. Homeostatic levels of p62 control cytoplasmic inclusion body formation in autophagy-deficient mice. Cell 2007; 131: 1149-1163.

27. Sun HY, Wang NP, Kerendi F, Halkos M, Kin H, Guyton RA et al. Hypoxic postconditioning reduces cardiomyocyte loss by inhibiting ROS generation and intracellular $\mathrm{Ca} 2+$ overload. Am J Physiol Heart Circ Physiol 2005; 288: H1900-H1908.

28. Staudt Y, Mobini R, Fu M, Felix SB, Kuhn JP, Staudt A. Beta1-adrenoceptor antibodies induce apoptosis in adult isolated cardiomyocytes. Eur J Pharmacol 2003; 466: 1-6.

29. Zhu H, Tannous $P$, Johnstone JL, Kong Y, Shelton JM, Richardson JA et al. Cardiac autophagy is a maladaptive response to hemodynamic stress. J Clin Invest 2007; 117: 1782-1793.

30. Gottlieb RA, Andres AM, Sin J, Taylor DP. Untangling autophagy measurements: all fluxed up. Circ Res 2015; 116: 504-514.

31. Gallo R, Padurean A, Jayaraman T, Marx S, Roque M, Adelman S et al. Inhibition of intimal thickening after balloon angioplasty in porcine coronary arteries by targeting regulators of the cell cycle. Circulation 1999; 99: 2164-2170.

32. Liu HR, Zhao RR, Zhi JM, Wu BW, Fu ML. Screening of serum autoantibodies to cardiac beta1-adrenoceptors and M2-muscarinic acetylcholine receptors in 408 healthy subjects of varying ages. Autoimmunity 1999; 29: 43-51.

(c) Cell Death and Disease is an open-access journal published by Nature Publishing Group. This work is licensed under a Creative Commons Attribution 4.0 International License. The images or other third party material in this article are included in the article's Creative Commons license, unless indicated otherwise in the credit line; if the material is not included under the Creative Commons license, users will need to obtain permission from the license holder to reproduce the material. To view a copy of this license, visit http://creativecommons.org/licenses/by/4.0/

Supplementary Information accompanies this paper on Cell Death and Disease website (http://www.nature.com/cddis) 